\title{
Rilonacept (IL-1 TRAP) for treatment of colchicine resistant familial mediterranean fever (FMF): a randomized, multicenter double-blinded, alternating treatment trial
}

\author{
PJ Hashkes ${ }^{1,8^{*}}$, SJ Spalding ${ }^{1}$, EH Giannini ${ }^{2}$, B Huang ${ }^{2}$, G Park ${ }^{3}$, KS Barron ${ }^{3}$, MH Weisman ${ }^{4}$, N Pashinian ${ }^{4}$, AO Reiff ${ }^{5}$, \\ J Samuels ${ }^{6}$, D Wright ${ }^{7}$, DL Kastner ${ }^{3}$, DJ Lovell ${ }^{2}$
}

From 18th Pediatric Rheumatology European Society (PReS) Congress

Bruges, Belgium. 14-18 September 2011

\section{Background}

There is no current treatment alternative for patients with FMF whose disease is resistant to, or do not tolerate colchicine. Since pyrin has an important role in IL$1 \beta$ regulation we hypothesize that IL-1 inhibition will decrease the number of FMF attacks in these patients.

\section{Aim}

To determine if rilonacept, a fusion protein that binds and neutralizes IL-1, decreases the number of FMF attacks compared to placebo.

\section{Methods}

Subjects were FMF patients $\geq 4$ years of age recruited at 6 U.S. sites, who had at least 1 FMF attack per month despite receiving adequate doses of, or who were intolerant of colchicine. Subjects received two 3-month courses of rilonacept (Arm A) at $2.2 \mathrm{mg} / \mathrm{kg}(\max 160$ $\mathrm{mg}$ ) by weekly SC injection and two 3-month courses of placebo (Arm B). Patients were randomized to 1 of 4 treatment sequences ( $\mathrm{ABAB}, \mathrm{BABA}, \mathrm{ABBA}, \mathrm{BAAB})$. Escape visits were allowed to permit switching arms (blinding was maintained) for patients with at least 2 attacks within a course. The primary outcome was the difference of FMF attacks between rilonacept and placebo courses with responders defined as subjects with a $>40 \%$ difference. Results were analyzed by paired $t$-and signed rank tests.

\section{Results}

Fourteen subjects were randomized, 8 males and 6 females, mean $( \pm \mathrm{SD})$ age $24.4 \pm 11.8$ years (range 4.5 47.3; 4 patients $<18$ years), disease duration $17.5 \pm 12.6$ yrs, with a baseline of $3.1 \pm 2.0$ attacks per month. Eleven completed the full study and 3 dropped out (1 due to lack of efficacy, 1 due to distance from study site and 1 lost to follow-up). Among 12 patients who completed at least 2 treatment courses the mean number of attacks per month on rilonacept was $1.0 \pm 1.2$ vs. $1.8 \pm 0.9$ on placebo $(\mathrm{P}=0.021$ by paired $\mathrm{t}$-test and 0.027 by signed rank test). There were 8 responders; all 4 non-responders were adults. There were 2 respiratory infection SAEs, 1 on rilonacept and 1 on placebo. Injections site reactions were significantly more frequent with rilonacept but no differences were seen in other adverse events, including infections.

\section{Conclusions}

Rilonacept significantly reduced the number of FMF attacks and had an acceptable safety profile. IL-1 inhibition is a treatment option for most (especially children) colchicine resistant FMF patients.

\section{Author details \\ ${ }^{1}$ Cleveland Clinic Foundation, OH, USA. ${ }^{2}$ Cincinnati Children's Hospital Medical Center, OH, USA. ${ }^{3}$ National Institutes of Health, MD, USA. ${ }^{4}$ Cedar- Sinai Medical Center, CA, USA. ${ }^{5}$ Children's Hospital of Los Angeles, CA, USA.}

* Correspondence: hashkesp@szmc.org.il

${ }^{1}$ Cleveland Clinic Foundation, OH, USA

Full list of author information is available at the end of the article 
Published: 14 September 2011

doi:10.1186/1546-0096-9-S1-038

Cite this article as: Hashkes et al:: Rilonacept (IL-1 TRAP) for treatment of colchicine resistant familial mediterranean fever (FMF): a randomized, multicenter double-blinded, alternating treatment trial. Pediatric

Rheumatology 2011 9(Suppl 1):038.

Submit your next manuscript to BioMed Central and take full advantage of:

- Convenient online submission

- Thorough peer review

- No space constraints or color figure charges

- Immediate publication on acceptance

- Inclusion in PubMed, CAS, Scopus and Google Scholar

- Research which is freely available for redistribution

Submit your manuscript at www.biomedcentral.com/submit
C Biomed Central 